\title{
Cannes 1999
}

\author{
By Ron Holloway
}

Fall 1999 Issue of KINEMA

THE 52nd CANNES FESTIVAL (12-23 May 1999) will go down in the books as the one in which a pair of unheralded films emerged as surprise winners: Luc and Jean Pierre Dardenne's Rosetta (Belgium-France) was awarded the Golden Palm, while Bruno Dumont's L'Humanité (Humanity) (France) received the followup Grand Prize of the Jury. In addition, Emmanuel Schotté was named Best Actor for his performance in L'Humanité, while Émilie Dequenne as Rosetta shared the Best Actress award with Sévérine Caneele in L'Humanité - remarkable, to say the least, for all are nonprofessionals. For that matter, the directors share a common fortune: these were the second feature films for both, they had previously appeared several documentaries) with feature films in the Directors Fortnight at Cannes, and their production bases in Liège (Belgium) and Lille (France) are only a short drive away from each other.

Programmed at the 1996 Directors Fortnight, Luc and Jean-Pierre Dardenne's La Promesse (The Promise) went on to win a bundle of prizes at international festivals, including the Grand Prix and the International Critics (FIPRESCI) Award at Valladolid. The Promise is one of those feature films in which the lines between fiction and documentary are effectively wiped out altogether. The 15-year-old Igor, a non-professional actor picked from the streets, spends days picking wallets and working for his abusive father, who exploits illegal immigrants from Africa and Bosnia in search of work on construction sites - until, one day, the lad comes of age and rebels against his father.

By contrast, Rosetta, a disarmingly frank 18-year-old girl (Émilie Dequenne), fights to keep her job in an ongoing struggle to find her place in the world. When work is taken away from her, she bounces back, more determined than ever to find another job - despite a drunken mother and at the cost of losing a friend. Indeed, a nonprofessional carries the film on presence alone (a trademark of the Liège-based Dardenne brothers), and Émilie Dequenne is so convincing as Rosetta that one hopes to see her contend for festival honours again somewhere.

Programmed at the 1997 Directors Fortnight, Bruno Dumont's La vie de Jésus went on to win an armful of awards, among them the Prix Jean Vigo. Set in the industrial northeast of France, one particular scene set the director (who graduated with a master's degree in philosophy before turning to cinema) apart: sexual copulation between the epileptic protagonist (given the name of Jesus, no less) and his working-class girlfriend, which takes place in broad daylight in an open field. Far from being offensive or scandalous, this low-key, compassionate scene alleviates and counter-balances much of the evil and violence to follow.

L'Humanité, again, is a film about sex and death. Pharaon, a widowed middle-aged police detective, is at heart a gentle person with a sense of duty that can drive him to tears when brought face to face with the miseries of his job. Living with his mother in Bailleul, a provincial hamlet in which nothing really goes unseen because everyone knows everybody, he communicates silently with his namesake in a painting on his bedroom wall - a self-portrait of his grandfather, Pharaon de Winter (1849-1924). The local artist and portrait painter, who belonged to the French realist school, excelled in religious scenes or subjects closest to him as a way to interpret good and evil and better understand humanity. In one key sequence Pharaon journeys to Lille to present his grandfather's portrait to an art museum about to open an exhibition of Pharaon de Winter's works dating from the 1880s.

As for the loose narrative thread, Dumont appears to pay homage to Bresson and Bernanos. Pharaon (Emmanuel Schotté) is enamoured by his girlfriend-neighbour Domino (Séverine Caneele), a robustly alive young factory worker, who in turn is physically attracted to Joseph, a vulgar type who's there to satisfy her lewd dependance on sex. Since Domino is fond of Pharaon and leans on his gentle nature for respite from the callous Joseph, the trio often spend the weekend together - and it's on one of these outings to the Calais coast that their contrasting personality traits are clearly drawn. Meanwhile, Pharaon is troubled because he cannot solve a heinous murder: a young girl has been raped and brutally murdered, her body dumped in the woods. Enter the police chief, a timid and mediocre guardian of the law, who can get nowhere. It's as 
though the crime has been covered completely by the silent, vast, harsh, mother-earth landscape of Flanders - the "sacred" element in this Jansenist treatise on fallen humanity.

Some competing entries stood out as startling sociopolitical statements on prevailing ideologies that disturb as well as question. Amos Gitai's Kadosh (Sacred, Israel-France), the first Israeli film in a quarter-century to compete at Cannes, was partially shot in Mea Shearim, Jerusalem's ultra-orthodox Jewish quarter, where tourists are often attacked on the streets because of affronts to the accepted dress code. Co-scripted with Eliette Abecassis - because he wanted a woman's perspective on the decisions facing the two women in the story - Sacred pairs the fate of sisters, Rivka and Malka, who live in a community where the rabbi has the last say. Because Rivka has been barren for ten years, the rabbi forces her husband to repudiate the woman he dearly loves in favour of another wife - although Rivka's clandestine visit to a clinic confirms that it's the husband, in fact, who's impotent. As for the attractive but unmarried Malka, the rabbi succeeds again to manipulate the destiny of a reluctant soul in the name of ultra religious principles: he forces her to marry his abrasively religious assistant, a decision that can only lead to calamity and cynical defiance. In the end, Rivka chooses resignation and death by heartbreak, Malka rebellion and freedom.

At first glance, Kish Tales (Ghesse haye kish, Iran), an omnibus film set on the duty-free resort island of Kish (in the Persian Gulf some 15 kilometres off the coast), may not seem socially engaged or politically motivated. But the idea came from Mohsen Makhmalbaf, a progressive figure in the Iranian film renaissance who is currently promoting the first Kish International Film Festival in early December. To date, five Kish Tales have been completed - directed by Mohsen Makhmalbaf, Abolfazl Jalili, Nasser Taghvai, Rakhshan Bani-Etemad, and Bahram Beizai - with a sixth one by Dariush Mehrjui currently in production. The Cannes festival committee thought so highly of what they saw that three films were arbitrarily linked together to form a competition entry. Afterwards, the Karlovy Vary festival committee booked the others.

Mohsen Makhmalbaf's The Door, the best in the series, impresses as a lyrical film poem about a man tramping across the dunes with a wooden door on his back, followed by his young daughter with a goat in tow. When the pair reach the sea, they meet a man who offers to buy the door, asserting that it's an antique of some value. As in Roman Polanski's similarly constructed short feature classic, Two Men and a Wardrobe (1959), nothing more happens in The Door, which may herald a new style of poetic cinema in contemporary Iranian filmmaking.

Although the Hollywood studios were conspicuously absent from this year's Cannes, the four American entries in the competition fared well with the critics and fit the image of a festival proud of its record of encouraging auteur directors and new trends in cinema. Jim Jarmusch's Ghost Dog: The Way of the Samurai links Samurai movie myths with Manhattan mafia fables in an entertaining story that spoofs both genres and in a string of hilarious sequences has a black gunman chatting amicably with a Haitian ice-cream seller in cross cultural lingo that requires subtitles. Tim Robbins's The Cradle Will Rock, with its title spotlighting Orson Welles's legendary Federal Theater production of 1936, fascinates most as an historical document on Manhattan's cultural and political climate at the height of the Depression just before the Second World War - the era of Diego Rivera and Nelson Rockefeller, Kurt Weill and Bertolt Brecht, John Houseman and Orson Welles, the latter staging together Weill's musical comedy The Cradle Will Rock despite a government order to close the performance on the eve of the premiere.

In John Sayles's Limbo the thriller genre is turned upside-down by leaving the ending open and the vulnerable protagonists stranded on an isolated Alaskan island where apparently other "losers" have previously perished. When this talented writer-director's pungent dialogue loses some of its zest, then the eye is pleasingly distracted by master cameraman Haskell Wexler's picturesque location shots. David Lynch's The Straight Story took fans and critics by surprise. Based on a true story about an Iowa old-timer, Alvin Ray Straight (Richard Farnsworth, in the role of a lifetime), who travels on the perch of a lawn-mower across the Mississippi to visit his ailing brother in Wisconsin (Harry Dean Stanton, in a delightful cameo), this light bucolic tale set in the summer of 1994 captures the very essence of slow-paced life in the American Midwest.

The press favourites for Cannes Palms went home practically empty-handed. Atom Egoyan's Felicia's Journey (Canada-UK), particularly memorable for its muted, forceful, character-acting performance by Bob Hoskins as a kindly Birmingham bachelor, borrows freely from Cocteau and Hitchcock to fashion a tightly woven tale about a serial killer who preys on homeless girls and is stymied when he learns that his lat- 
est victim, an Irish girl (Elaine Cassidy) in search of her one-fling lover, just happens to be repulsively pregnant. Equally overlooked for festival kudos was Michael Winterbottom's Wonderland (UK), the story of three street-wise sisters whose on-and-off love affairs are anything but emotionally rewarding. Winterbottom charges his film with some scenes of high tragicomedy (the neighbour's barking dog as a recurring motif) and some winsome improvisational acting along the lines of Mike Leigh's absurd melodramas - indeed, just the efforts of the rather homely Nadia (Gina McKee) to meet a beau make for appealingly poignant moments.

Takeshi Kitano's Kikujiro (Japan), the triumph of this festival, showed another side of a director whose previous thematic edge has been violence anchored to Tokyo's gangster milieu. Kikujiro (Takeshi Kitano), a rumdum drifter whose natural habitat is the racetrack, reluctantly accompanies Masao, a sensitive 9-year-old who has never met his mother, on a summer journey to find her - with the result that Kikujiro rediscovers his own childhood and effectively assumes parental responsibility when he stumbles upon the truth: the boy's mother, married again, is devoting herself to a new family. Pedro Almodóvar's Todo sobre mi madre (All about My Mother, Spain-France), the favourite of the critics, delighted with its panoply of oddball characters, comic twists, and swift narrative pace - a cross between a kitschy melodrama and an afternoon soap. As a story, All about My Mother is about as outlandish as it can get: a transvestite whore who was once a family man, a nun who gets pregnant and dies of AIDS, a lesbian junkie and an emotionally disturbed actress. But hand the directorial reins to this talented auteur, and you have a comedy that draws its best lines from the stuff of sin, death, and disease. Pedro Almodóvar was awarded Best Director by the international jury.

No festival director is more adept at programming key scheduling slots than Gilles Jacob. Give him a pair of national religious holidays (Ascension Thursday and Pentecost) serving as calendar bookends, and you can be sure he will fill the spacious Salle Lumière with appropriate spectacles to accommodate the crowds. Nikita Mikhalkov's opulently expensive The Barber of Siberia (Russia), running out-of-competition, opened the festival. On the following Sunday Raoul Ruiz's adaptation of Marcel Proust's Le temps retrouvé (Time Regained, France-Italy) was programmed back-to-back with Chen Kaige's The Emperor and the Assassin (China-Japan-France). And the gala awards ceremony took place on the Pentecost weekend.

The Emperor and the Assassin was billed as the most expensive and expansive Chinese production ever made - indeed, this costly national epic about the conquest of rival kingdoms to mold ancient China into a single empire in the 3rd century BC could only be made in a socialist state with an army of extras at the director's disposal. Never mind that the decor and costumes are so sumptuous as to distract even from the beauty of Gong $\mathrm{Li}$, and who really cares if the maze of court intrigues and assassination plots are hard to keep track of. It's that battlefield showdown worthy of Shakespeare's Macbeth and reminiscent of Kurosawa's Throne of Blood that counts in the long run. The International Jury awarded The Emperor and the Assassin the Technical Prize.

Marcel Proust's (1871-1922) seven-volume Remembrance of Things Past (published between 1913 and 1927), based on the author's lifetime experiences and raised to the high art of fictional recollection, ranks with James Joyce's Ulysses as a classic "stream of consciousness" achievement. Proust's world is like an interconnected gossip column penned by a rich intellectual snob with a refined sense of the comic, for whom music, painting, and literature in particular matter far more than society. And his remarkable gift for penetrating human passions makes him as readable today as yesterday.

Raoul Ruíz's Time Regained (the last volume of the opus was published in 1927, five years after the author's death) opens with Proust on his deathbed in the cork-lined room where he spent much of his life as a victim of asthma. We hear his voice (spoken by Patrice Chéreau) as the writer looks through photos to recall events in his life. Gradually, the real characters of his recollections become the fictional ones of his literary writings. The lost paradise of his childhood gives way to literary salons in Paris, the vast comédie humaine that surrounded and supported him, followed by the trauma of the First World War and the shaping of a new postwar society. All the performances are first-rate: Catherine Deneuve as Odette de Crécy, Emmanuelle Béart as Gilberte, Chiara Mastroianni as Albertine, Marie-France Pisier as Madame Simone Verdurin, and John Malkovich as the loony, aristocratic Baron de Charlus.

Two months before The Barber of Siberia (Russia-France) opened the Cannes festival, actor-director Nikita Mikhalkov had already stunned audiences and critics with his controversial screen incarnation of Tsar Alexander III in a production that is reckoned to be the most expensive (US $\$ 45$ million, including $\$ 10$ million in 
Russian film funds) and lavish in Soviet-Russian film history. True, his appearance as Alexander III (Russian tsar from 1881 to 1894) is little more than a cameo. But when Mikhalkov staged the world premiere of The Barber of Siberia on February 20th, Russia's Memorial Day for "Defenders of the Fatherland," in the 5,000-seat Kremlin Palace, the event was attended by Moscow's political elite and had enough pomp and circumstance to shame Hollywood. Even the problem of spoken dialogue - $70 \%$ of the film was shot in English - was effectively surmounted for the Russian public by an over-talk on the soundtrack - featuring Nikita's own voice.

As with most historic melodramas, the story line in The Barber of Siberia - dedicated "to the honour of Russian officers" and set in 1885 - is banal and contrived from beginning to end. When a young cadet from a noble family, Andrei Tolstoy (Oleg Menshikov), meets the lovely American adventuress Jane Callahan (Julia Ormond) on a train, he interrupts her reading of Anna Karenina to fall head over heels in love with her. Later, when his declaration of passion is funnelled through motifs from Mozart's The Marriage of Figaro at an operatic performance, the brash cadet loses his head altogether, thrashes his commanding officer before the crowd, and is banished to Siberia. Jane, pregnant with Andrei's child, spends the rest of the film looking for him. One sequence, however, erases the discomfort left by the ceaseless pounding of vapid dialogue: the departure of a chain-gang of young rebels from a railway station, tightly edited and highly charged with remarkable camera-shots (Pavel Lebeshev) and a resounding soundtrack of pitched voices and locomotive cacophony.

Moloch (Russia-Germany) defies description, for this German-funded (80 per cent of the budget) coproduction about Eva Braun and Adolf Hitler, directed by a Russian with Russian actors speaking dubbed German, sounds rather implausible. But Alexander Sokurov is not an ordinary Russian director - among his 30-plus credits as a director is a 10-minute montage-documentary titled Sonata for Hitler (1979), made 20 years ago. Nor should poet Yury Arabov, the screenwriter for all of Sokurov's feature films, be discounted - the original script, titled "The Mystery of the Mountain," focussed on a day from dawn to dusk atop the Führer's Alpine retreat in Berchtesgaden in the late spring of 1942, a couple of months before the German defeat at Stalingrad. Although Yury Arabov and Marina Koreneva were awarded Best Screenplay, far more fitting would have been recognition given to Russian cameraman Alexei Federov for the film's visual imagery and conceptual design: it's as though he shot everything through a veil of gauze.

Moloch was not the only competing film that left critics puzzled, confused, or flabbergasted. Others were Peter Greenaway's black comedy, 81/2 Women (UK-Germany-Netherlands-Luxembourg), a dubious homage to Fellini's $81 / 2$ classic set in a Japanese bordello where customers are serviced with oriental sex fantasies; Leos Carax's Pola $X$ (France-Germany-Japan-Switzerland), whose impulsive hack-writer protagonist retreads in a modern context the mental breakdown charted in Herman Melville's Pierre, or The Ambiguities (published 1852); and Manoel de Oliveira's A carta (The Letter, Portugal-France-Spain), an unresolved, old-fashioned moral tale about a married woman (Chiara Mastroianni) pulled between respect for her doctor-husband and love for a young singer with the reputation of a roué. The Letter received the Prize of the Jury.

A pair of literary adaptations that caught the eye if only because the directors obviously share a reverence for the same social viewpoints and political statements as the writers do and manage to convey these convictions to the acting ensemble. In Arturo Ripstein's adaptation of Colombian writer Gabriel García Márquez's El Colonel no tiene quien le escriba (Nobody Writes to the Colonel) (Mexico-Spain-France), about an old, impoverished revolutionary awaiting a pension that will never come, poignant performances by Fernando Lujan as the Colonel and Marisa Paredes as his wife underscore the sentiment that decency alone is not enough to maintain self-respect. And in Marco Bellochio's adaptation of Pirandello's La Balia (The Nanny, Italy), poverty and oppression of the working class in Italy at the turn of the century is effectively underscored in the person of an illiterate country-girl, Annetta (Maya Sansa). Madame Mori (Valeria Bruni Tadeschi in her best role to date) has a baby but cannot provide milk from her own breast, so a wet nurse is engaged - whose love for the child disrupts in turn the harmony of the household. The Nanny, well deserving of a festival award, is yet another example of the high artistic level at this year's festival.

An unforgettable event at Cannes 52? Surely it was the presence of Chengis Aitmatov, one of the great storytellers of our times who is currently Kyrgyzstan's ambassador to Brussels, for an honorary screening in the German Series at Olympia Cinema 3 of Frank Müller's Wo der Himmel auf die Erde trifft (Where the 
Sky Meets the Land). This poetic and personal documentary, whose main character is an elderly Kirghiz woman who lives alone in a tent on the steppes tending to her sheep and harassed from time to time by wolves, is remarkable for its breathtaking images of the mountainous landscape, matched with glimpses of the rituals and traditions practised over the ages until today by a nomadic people. One spectacular scene stands out in this 90-minute documentary: Müller was on hand for a contest of mounted horsemanship, a wild game to test the skills of both horse and rider. And there's a sober note as well: his shots of the native workers employed to operate a Canadian-owned gold-mine questions where the pollution caused by the mine might one day lead to an ecological disaster.

The short film competition in Cannes, judged by an independent jury, has become an delicacy cineastes are reluctant to bypass. For the shorts are not just gems of filmmaking. Often, too, they provide relief from those needlessly prolonged feature films in the big show. The program opened fittingly with Jarl Olsen's Devil Doll (Denmark), a one-minute laugh-parade about two young girls finding a "talking doll" on the beach. Then, as the filmmakers rose briefly from their seats for a moment in the spotlight, each was greeted with a shower of warm spontaneous applause.

John Paton and Matthew Ross's Food for Thought (USA) was another highlight. Given its humorous twist, one might figure this quick-food spoof to be British to the core, but the setting is typically American where types of all sorts can mix up their menus. By contrast, a pair of shorts from South Korea, Kim Daehyun's An Eternity and Song Ilgon's The Picnic, are moving statements on life and death, the latter about a young businessman who, facing financial ruin, takes his family on a fatal picnic in the woods. Black humour along the lines of Food for Thought was served up again in Toby Leslie and Hugo Currie's The Cookie Thief (UK), and it was at the core of Don Hertzfeldt's animated Billy's Balloon (USA) - indeed, the short film format is a haven for black humour.

The Golden Palm was awarded to a 10-minute animation entry: Wendy Tilby and Amanda Forbis's When the Day Breaks (Canada), a National Film Board presentation about what happens when Rudy the Pig unexpectedly loses a friend. And the Grand Prize of the Jury went to Rodolphe Marconi's Stop (France), a 15-minute live-action family tale about a grown son who back away from the painful decision to visit his father in the hospital, a person whom he has not seen since he was two and doesn't even remember.

La Cinéfondation, launched last year by Gilles Jacob to foster tomorrow's directorial talent, has grown from two programs to four - and the quality has risen with it. Altogether, 20 films of all genres and formats were selected from film schools and university film programs in Austria, Australia, Czech Republic, Denmark, France, Germany, Greece, Israel, Italy, Japan, South Korea, Poland, Slovakia, Switzerland, Taiwan, UK, Ukraine, and USA. Although the audience consisted primarily of the students themselves, supported by their professors and shooting teams, talent nevertheless has a way of rising to the surface. A coming director to keep an eye on? How about Emily Young, whose Second Hand (UK-Poland) was awarded First prize by the same independent jury that judged the short film entries. Second Hand is the story of a young girl who obtains on credit a school skirt from a second hand uniform sale, and then has to find a way to pay for it. The short feature, a coproduction by the London Film School and the Lód Film School, was made by an American who has studied in Philadelphia, Edinburgh, London, and Lódż in Poland.

\section{THE 1999 SIDEBARS: HIGHLIGHTS AND HAPPENINGS}

\section{Special screenings}

\section{Mein liebster Feind (My Beloved Enemy, Germany-Finland-UK-USA), by Werner Herzog}

Werner Herzog, alias Werner Stipetic, made five films with Klaus Kinski (1926-1991), alias Klaus-Günther Nakszynski -- and nearly all of them were an integral part of Cannes festival history: Aguirre, Wrath of God (1972), Nosferatu, Phantom of the Night (1978), Woyzeck (1979), Fitzcarraldo (1982), and Cobra Verde (1987). Taken altogether, they compose a unique, personal, thematic cycle on shattered lives in isolated places, the series par excellence in the oeuvre of Werner Herzog.

The story goes that when Herzog approached the enfant terrible to collaborate with him on Aguirre, Kinski was riding a wave of madman popularity at studios in Europe and Hollywood. The pair were doomed to clash from the beginning, particularly as the director was just as mad for shooting in the Amazones as the 
actor was for accepting the role of a deranged conquistador. Towards the end of the shoot, Kinski erupted -and threatened to leave the set if a technician he disliked was not fired on the spot. Here's Herzog's version of the off-repeated story about the showdown: "I didn't have a gun -- he just made that up later to cast a better light upon himself. I told him I have a rifle, and he would only make it as far as the next bend in the river before he had eight bullets in his head -- the ninth would be for me."

Thanks to its reception in the Directors Fortnight at the 1973 Cannes festival and its subsequent release on art house circuits in Europe and America, Aguirre went on to become an acclaimed classic in the New German Cinema movement. And thanks to the support of Tom Luddy and Bill Pence at the Telluride film festival, Werner Herzog became an independent producer-director who could pretty much chart his own production future. Word went out that if you wished to contact Werner for projects or interviews, then the two addresses were Cannes in May (either at the Blue Bar or the Majestic Bar) or Telluride in the Colorado Rockies in September (where he showed up for ten years running). The appearance of Herzog and Kinski at Telluride in My Beloved Enemy adds a nostalgic note to this personal documentary about a working relationship that wasn't always turbulent -- that amicable footage, of course, came from the Telluride archive.

Six years after Aguirre, Herzog and Kinski collaborated again on back-to-back productions: the remake of F.W. Murnau's Nosferatu and a screen adaptation of Georg Büchner's expressionistic play Woyzeck. In Nosferatu, Isabelle Adjani dared a rat scene in much the same manner as Kinski toyed with monkeys on a raft in Aguirre -- both sequences contain haunting Herzog images which are sending shivers down your back. In Woyzeck, shot in a picturesque Czech village, Kinski was given one of the best opportunities of his screen career to demonstrate the full range of his acting skills.

Fitzcarraldo, awarded the Best Director prize at Cannes, brought the pair back to the Amazon jungle, this time in the company of Claudia Cardinale. As chronicled in Les Blank's documentary Burden of Dreams (USA, 1982), this mad tale about an adventurer determined to drag a ship over a mountain took two years of interrupted work to complete -- a task that could only be resolved in the end by reconstructing a waterfallchute on the backlot of the Bavaria Studio in Munich. Cobra Verde, inspired by the writings of Bruce Chatwin, found Herzog and Kinski together for the last time on the west coast of Africa. Its focus is on the slave trade that boomed here two centuries ago -- with Kinski as the mediator of its shame and madness.

\section{Adieu, plancher des vaches (Farewell, Home Sweet Home, France-Switzerland-Italy), by Otar Yoseliani \\ Adieu, plancher des vaches marked the fourth visit to Cannes by Otar Yoseliani, the Georgian director with an address now in Paris. Back in 1968, Yoseliani was introduced to the "Week of the Critics" audience in the Salle Bazin of the old Palais des Festivals by the late French critic Louis Marcorelles. His film, When Leaves Fall (1966-68), a gentle tale about a lad whose nonchalant life-style reflected traditional Georgian mores rather than conformist Soviet work ethics, had already been shelved for two years with little chance for release -- had not French critics put in a good word for both the director and the film with Goskino in Moscow. When Leaves Fall, awarded both the Prix Georges Sadoul and the International Critics (FIPRESCI) Prize, launched Yoseliani as an auteur on the spot in Cannes.}

The French critics were unable to free Yoseliani's equally provocative April (1961/87), a short film destined to be shelved for 16 years until Michael Gorbachev's perestroika policy brought reform and change to the Soviet film industry. And it took Pierre-Henri Deleau four years to coax Soviet film authorities into allowing Yoseliani's lyrical Once There Lived a Song-Thrush (1970/74) to be presented at the Directors Fortnight in 1974. A poignant tragicomedy, about a young man in an orchestra who has time for everybody save for himself, the film was an immediate critical success in Cannes.

Yoseliani's record of shelved feature films remained intact when his Pastorale (1976/81), a rambling, bucolic tale about a young string quartet spending their summer holidays rehearsing in the country, was banned without any specific reasons given. Five years later, the International Forum of Young Cinema obtained permission from Goskino to present Pastorale at the 1981 Berlinale -- and the film was promptly awarded another FIPRESCI Prize. By this time, Yoseliani had received artist-in-residence grants from Paris and Berlin, and he was allowed to follow Andrei Tarkovsky into exile. 
A film artist with an eye for composition and an ear for music, his Georgian documentaries and short films -- Watercolor (1958), Sapovnela, the Song about Flowers (1959), April (1961), Old Georgian Song (1969) -were characterized by brilliant colours, natural landscapes, Caucasian ballads, and a liking for the naive and surreal as found in the paintings of Pirosmani and other national artists. Thus, upon arriving in western Europe, he had no trouble finding work as a documentary filmmaker with a keen eye for people and settings: Euzkadi: The Basque Country in Summer '82 (1982), programmed at the Directors Fortnight, and A Little Monastery in Tuscany (1988).

All of Otar Yoseliani's feature films are rooted in the real world. His position on using nonprofessionals over professional actors has left some producers shaking their heads, for sometimes Yoseliani calls upon friends to play roles that fit -- as in Favourites of the Moon (1984), awarded at Venice, in which French critic Marcel Martin appears in a cameo. Gradually, over the years, he has received the international co-production backing he needs to continue making quaint features packed with light humour, curious twists, and absurd touches: And Then There Was Light (1989), awarded at Venice, followed by Chasing Butterflies (1992), the three-part documentary Alone, Georgia (1994), and Brigands: Chapter VII (1996).

In Farewell, Home Sweet Home Nicolas, a wealthy young man still tied to his mother's skirt, leaves the family estate regularly for excursions to Paris to work on odd jobs and meet new friends. Blind to the truth, he views his new acquaintances -- tramps, thieves, do-nothings -- as genuine heroes. In love with the waitress Paulette, Nicolas doesn't notice that the maid Valerie is interested in him. Paulette, in turn, likes the shady Gaston, who's out to get whatever he can. Meanwhile, Nicolas's mother jet-sets around Europe on business trips, while his tipsy father -- Otar Yoseliani as the eccentric master-of-the-house -- is either out hunting or in the company of a pet stork.

\section{VIEWS FROM UN CERTAIN REGARD}

\section{Peau neuve (New Skin, France), by Emilie Deleuze}

Awarded the FIPRESCI Prize, the citation is all the more remarkable because the film was given to a competition entry. New Skin was developed out of a year-long visit to a training centre for skilled workers who operate heavy machinery on construction sites. Alain, married and the father of a young daughter, abruptly discards his demeaning job as a video-game-proofer to enroll in a four-month training course in Corrèze, far from Paris in the heart of France, where he meets Manu, an "idiot" in the Dostoevski mold who can see through people and yet remains a mystery unto himself. The odd couple, both interpreted by professional actors, "hit it off" when Alain realizes that Manu not only happens to like heavy-duty machinery, but he also uses his skills to neutralize the daily routine of violence surrounding them. With three shorts and a telefeature to her credit, Emilie Deleuze was looking for a theme for her first feature that would be cut directly from working life and filmed on natural locations, but with an extra twist to set it apart from docu-drama and the fiction documentary. She succeeded admirably.

\section{Murana Simhasanam (Throne of Death, India), by Murali Nair}

Awarded the Caméra d'Or for Best First Feature Film, Throne of Death spotlighted the State of Kerala as a leading production centre in India today. The very fact that a London-based Indian director with only three short films to his credit could return to Kerala to make an hour-long debut feature within six weeks speaks well for a new liberal production policy in Kerala. The Throne of Death scores as a biting, pathetic tale about the first execution by electric chair of a poor thief from an impoverished community. Krishnan, a seasonal worker who lives with his family on an island without electricity, depends on odd jobs from a possessive landlord to feed his family. When he steals a bunch of coconuts from his master's grove to give his children something to eat, he unfortunately gets caught and is thrown in jail -- only to be accused by the magistrate of an unsolved murder that had happened some years before. Events get more out of hand when politicians take up Krishnan's cause in order to win election votes -- which, in turn, prompts the entire populace to greet the arrival of electricity by placing the thief on "the throne of death" to celebrate his execution. One disgrace follows another -- all are based on historical fact!

\section{Vanaprastham (The Last Dance, India), by Shaji Karun}

Best known to festival directors the world over as India's masterful cinematographer, Shaji Karun -- sometimes signed simply "Shaji" -- provided the late Indian director, Govinde Aravindan, with unforgettable images in the latter's cycle of mythology-oriented stories set in the State of Kerala. Indeed, Shaji's camera 
hardly seemed present at times when Aravindan turned his warm, perceptive gaze on nature, costumes, ritual, traditional dances and plays that characterize the glories of a national heritage in this southern-most corner of the Subcontinent. His breakthrough as director-cinematographer came with Piravi (Birth, 1988), a simple story that creates a sustaining mood by close attention to detail. The focus is on an aged father in a village who has heard that his son, a student at the University of Trivandrum, may have been arrested by the police for instigating unrest against the authorities. Swaham (Destined, 1994), invited to compete at the 1994 Cannes festival, sketches the plight of a widowed mother of four children whose small coffee-shop no longer returns enough income to feed the family. For his latest feature, Vanaprastham (The Last Dance), Shaji Karun returns to the traditions of dance and theatre that, back in the 1930s, required rigorous training on the part of performers. The hero is a boy of ten who embarks on a life-long apprenticeship to master the noble Kerala art form of Kathakali, a combination of dance, theatre, and pantomime.

\section{El Akhar (The Other, Egypt-France), by Youssef Chahine}

Youssef Chahine (also spelled Yusuf Shahin), with 38 films to his credit, seldom ducks controversy if he feels the cause is right. His "Alexandrian Trilogy" -- Alexandria - Now (1978), Adieu Bonaparte (1984) and Alexandria Again and Again (1990), was praised for blending past and present in personal statements of endearing affection for his birthplace, a city that has traditionally embraced all nationalities and religions with prejudice towards none. Lately, Chahine has been exercising his mandate as the best known and respected of Arab directors by challenging fanatical Islamic fundamentalism head-on. For making The Emigrant (1994), with its parallel to the "Story of Joseph" in the Bible, he was sued and brought to court. In Destiny (1997), a French-Egyptian production selected for the competition at Cannes, he chronicles the life of Averroës, the Arab medieval philosopher whose Commentaries on Aristotelian Thought helped considerably to drag Europe out of the Dark Ages. Now, in The Other, presented as the opening film in the Certain Regard, Chahine completes his cycle on the evils of blind fundamentalism with a Romeo and Juliet story adapted to current Egyptian religious mores. When Adam, son of wealthy parents who are allied to corrupt profiteers in the government, falls in love with Hanane, a young journalist from a humble family who believes in principles of honesty and integrity, Adam's mother steps in between them to show her true colours -- a fanatical extremist.

\section{Harem Suare (The Last Harem, Italy-France-Turkey), by Ferzan Ozpetek}

Two years ago, Ferzan Ozpetek's Hamam (Steam: The Turkish Bath), programmed in the Directors Fortnight, was one of the discoveries at Cannes. The intriguing story of a Turk living in Italy who is informed of inheriting a hamam back in Istanbul from a deceased aunt, the film unfolds as an unusual love triangle -man, wife, male lover -- set in a restored Turkish bath. Now, Ozpetek's The Last Harem was selected to close the Certain Regard. Set in Istanbul of 1904, just before the fall of the Ottoman Empire and with revolution already before the door of the Yildiz Palace, it's the story of Safiyè (Marie Gillain), an Italian girl who was bought by a pasha in the slave market at Cairo and presented to Sultan Abdulhamid as a present. There, with the help of a black eunuch, she rises quickly in the harem to become the Sultan's favourite. For it just so happens that the Sultan likes to listen to Verdi's La Traviata, but can't stand the unhappy ending -- so he asks Safiyè to rewrite the libretto for him. Weave the loose ends together, and you also have a futile love relationship between the Sultan's concubine and her eunuch. Placed side by side, Ferzan Ozpetek's two features seek to bridge the cultures of the Western world with the Oriental. As a Turk based in Rome, he's trying to unravel with a Westerner's eye one of the most crucial knots of his original culture: the end of the Ottoman Empire, portrayed in one of the dearest places to the imagination -- the harem.

Beresina oder die letzten Tage der Schweiz (Beresina, or The Last Days of Switzerland) (Switzerland-Germany-Austria), by Daniel Schmid

Daniel Schmid, a Swiss director whose name is linked to the New German Cinema movement, is best remembered at Cannes as the director of one of the most controversial films ever presented in the main program: Schatten der Engel (Shadow of Angels, 1976), starring Ingrid Caven and Rainer Werner Fassbinder in a screen adaptation of Fassbinder's drama The City, the Garbage and Death. He's also a directorial talent who moves easily between making films and staging operas, sometimes combining both aesthetics -- as in the experimental La Paloma (1974), presented at the Berlinale, and Tosca's Kiss (1984), a documentary made at an old peoples home for retired opera singers in Milan. Beresina is billed as a black comedy under the teasing subtitle The Last Days of Switzerland. It's the story of Irina (Elena Panova), a lovely Russian call-girl who falls in love with the Alps the day she arrives in Switzerland, although she knows all too well 
that her entire family back in Russia depend on her for support. Irina's clientele, arranged through a shady doctor acquaintance, includes the cream of Swiss interest groups -- businessmen, politicians, military officers, and media moguls -- some of whom will go so far as to propose marriage. The trick, however, is to obtain a Swiss passport -- but only if she agrees to work as an informer.

\section{Sicilia! (France-Italy), by Danièle Huillet, and Jean-Marie Straub}

When Jean Marie Straub and Danièle Huillet's stage adaptation of Elio Vittorini's seminal antifascist novel Conversazione in Sicilia premiered last year during the Easter season at the Buti Municipal Theatre in Italy, Sicilia! received congratulations from luminaries in film and literary circles. Jean-Luc Godard: "Thank you for giving us such beautiful, lucid moments. They stand out in a dark and stupid world." Peter Handke: "You have discovered, shown, exploded cinema in my heart. Sicilia! is all your work in one, heightened rage and gentleness." Certainly, Huillet and Straub deserve to be welcomed back at Cannes. But when an attempt was made to present their static-camera, Greek-arena film version of Arnold Schoenberg's opera Moses and Aaron in a sidebar at the 1974 Cannes festival -- with its dedication to Holger Meins, a Straub colleague at the Berlin Film Academy who was linked to the Baader-Meinhof Group and died in prison of starvation -- the pair came under heavy attack in the political arena. In Sicilia! Silverio, the alter ego of Italian writer Elio Vittorini (1908-1966), returns home from the north of Italy after 15 years to visit his mother. Although Conversations in Sicily served in 1939 as a powerful political metaphor that angered fascist literary critics and was banned in 1942, the novel-play-film in Huillet-Straub's hands still fascinates as a minutely structured journey of initiation from childhood to manhood.

\section{Les Passagers (The Passengers, France), by Jean-Claude Guiguet}

Hardly a newcomer to Cannes, Jean-Claude Guiguet came to filmmaking from work as a professional film critic. When he was 30, his short feature, Les belles manières (Nice Manners) (1978), was presented in the Directors Fortnight, followed by an invitation nearly a decade later to present Faubourg Saint-Martin (1986) in the Week of the Critics, for which he was awarded the Prix Georges Sadoul. Now he's back at Cannes for the third time with The Passengers, the title referring to commuters who get on and off the new tram route in the north of Paris that runs between Saint-Denis and Bobigny. Among the regular passengers is a woman (Véronique Silver), who serves as the narrator on the comédie humaine that unfolds before her and our eyes. She introduces the lovely Anna, the handsome Pierre, the pair David and Marco, and the winsome Isabelle -- most of whom are familiar faces from Guiguet's previous films. Each of the passengers, of course, has a story to tell -- some funny and verging on the burlesque, others poignant with a twist of the pathetic, depending on their job or position in life or personal style of living. Also, there are lessons to be drawn from heartaches and disappointments, from broken promises and the ever-present spectre of death. Jean-Claude Guiguet's forte as a filmmaker is that he can pair these experiences in such a way that the viewer is nudged to look around a bit more at life cruising by on the next tram-ride into the city.

\section{The Shade (France-USA), by Raphael Nadjari}

Raphael Nadjari's The Shade, a first feature film selected for Un Certain Regard, is not the first time that Dostoevski's short story "A Gentle Woman" has been brought to the screen. Robert Bresson, who turned to Dostoevski for thematic material on two different occasions, directed an acclaimed Une femme douce with Dominique Sanda in the title role. Stanislav Barabáš showed up at the 1968 Karlovy Vary film festival with a poignant Slovak version, after which he used this film as his calling card at West German TV stations when he departed Czechoslovakia after the Soviet invasion. And Polish director Mariusz Trelinski recently adapted A Gentle Woman (1995), starring Dominika Ostalowska, to current conditions in post-communist times. Queried why he shifted the setting for the story from Moscow to the Spanish-speaking Harlem section of New York City instead of to Paris, Nadjari had a ready and rather convincing answer: "Because New York has a lot of similarities with Moscow in the Russian 19th century. The story is really possible here. You don't have pawnbrokers in Paris." Thus, the one essential change in the literary classic: Simon (Richard Edson), sitting alone in his apartment and consumed with grief after his wife Anna (Lorie Marino) had committed suicide, is a Jewish pawnbroker instead of the Orthodox Christian in the original.

\section{La Genèse (Genesis, Mali-France), by Cheikh Oumar Sissoko}

Over the past five years directors from Mali have been invited to all the major sections at Cannes. Souleymane Cissé's Waati, the story of a South African girl coming of age while travelling through western and southern Africa, was in competition in 1995. Two years later, Abdoulaye's Ascofare's Faraw (Woman of the Sands, 
1997), the portrait a woman looking after her disabled husband while raising three children, was invited to the Week of the Critics. Oumar Sissoko previously directed a trio of feature films that placed him in the forefront of Black African Cinema: Garbage Boys (Nyamanton, 1986), about kids without desks in school who turn to garbage collecting in order to survive; Finzan (1989), about a young widow rebelling against the tradition of having to marry her dead husband's brother; and Guimba (1995), a ribald historical allegory about sexual power in a pre-colonial African empire. In Genesis the biblical story of Jacob and his sons takes on extra colour in a Mali context: traditional native garb, African social customs, a reconstructed Mali stone-village where three communities -- farmer-peasants, animal-raisers, and hunters -- are shown to be constantly in conflict with each other. Esau is played by Salif Keita, a popular Mali singer.

\section{The Personals (Taiwan), by Chen Kuo-Fu}

Of all the Asian entries screened at Cannes, this low-budget production from Taiwan was an audience favourite and had spectators giggling at the start and moved at the end. The idea for Chen Kuo-Fu's The Personals is as about as simple as they come. "I wasn't even thinking of a theme," confessed the director. "I just wanted get a lot of faces before the camera -- real faces, not faked ones. And I was sure that these faces would convey something about the world we live in." It's the story of sensitive young female eye-doctor (Rene Liu) who has been rejected by the married man she loves, so she places an ad in the personals of a newspaper to find a replacement. The results are overwhelming, and a rendezvous is arranged in a restaurant. As for her prospects, they run the full gamut of the human species: a homely man who proposes marriage right off the bat, another with a shoe fetish and the samples to try on, a bumpkin looking for a one-night-stand, a pimp and an actor and a conman -- you name it, or guess it, and up he pops with a line of gab to bring the roof down with laughter. Who are these people who feed off "personals"? Many in the film are nonprofessionals who have answered the director's own ad, while others are acquaintances, and a few have genuine acting talent. The twist comes at the end, for along the way the frustrated woman has been phoning her ex-lover to leave word of her encounters on the answering machine. One day, she receives a call back from the wife.

\section{NOTES AT THE DIRECTORS FORTNIGHT Wege in die Nacht (Paths in the Night, Germany), by Andreas Kleinert}

Chosen to open the Directors Fortnight, Paths in the Night confirms Andreas Kleinert as the film-poet in a new wave of talented directors emerging from eastern Germany. His diploma feature film at the Babelsberg Film School, Leb' wohl, Joseph (Farewell, Joseph, 1989), a black-and-white Kafkaesque film of cryptic symbols and enigmatic metaphors, was invited to compete at Locarno. His Verlorene Landschaft (Lost Landscape, 1993), invited to San Sebastian, scores as a surreal psychodrama set against bleak industrial ruins. His next two films -- Neben der Zeit (Outside Time, 1996), awarded at Cairo, and Im Namen der Unschuld (In the Name of Innocence, 1998), invited to Venice -- continued his investigations into the breakdown of relations in a decaying social structure. In Paths in the Night, shot again in black-and-white (cameraman Jürgen Jürges), the role of an ex-communist factory-manager who has lost his bearings in post-unification Germany was originally conceived as an ex-officer in the "Stasi" (State Security Police). The 55-year-old Walter (Hilmar Thate), at heart an idealist, can barely stomach being unemployed and living off his wife's earnings as a waitress. Spurred on by an undying belief in a better world, he recruits a pair of leathery simple-minded youngsters to ride Berlin's underground and city trains -- his "paths in the night" -- in search of vigilante actions to do good and fight evil -- with fatal consequences.

\section{Les convoyeurs attendent (The Carriers Are Waiting, Belgium-France-Switzerland), by Benoît Mariage}

Benoit Mariage came to the fiction film from work in television, where he had specialized in documentaries and reportage on social and political events. His assignments brought him to Africa on occasion, where he made a remarkable ethnographic film on nomad life in Mauritania and did a TV special on Burkina Faso. Then, after shooting the short feature Le Signaleur (The Signalman, 1997), he developed an ongoing project Les convoyeurs attendent into his first feature film. The Carriers Are Waiting refers to carrier-pigeons, one of which is Napoleon, the champion carrier raised by Felix, who lives next door to a Walloon family in an industrial area of Belgium. A poetic chronicle covering one year in the life of a family at the dawn of new millennium, events are seen mostly through the eyes of the 8-year-old daughter -- and from her viewpoint everyday life seems rather absurd. Her father (Benoit Poelvoorde), a loony reporter for a local newspaper, is always listening to the police band to catch a possible "scoop" -- a car accident, a bum dragged off to jail for 
disturbing the public, a farmer's crop damaged by a hail storm. Meanwhile, Dad is training his 15-year-old son to win a car in a contest by setting a new record for opening and closing a door -- 40,000 times in 24 hours! Often hilarious, sometimes sad and melancholic, this is the best Belgian tragicomedy since Jaco van Dormael's Toto le héros (1991).

\section{Kiemas (The Courtyard, Lithuania-France), by Valdas Navasaitis}

Valdas Navasaitis entered the Moscow Film School (VGIK) in 1983 together with Sharunas Bartas and has been collaborating with him ever since. The pair co-directed the impressive 12-minute documentary Tofalaria (1985), about a tribe of people on the verge of extinction in a mountainous area of Central Siberia. A film poet, Navasaitis has been occupied off and on with a trilogy of lyrical sketches about the seasons in Lithuania: Autumn Snow (1992) made during his VGIK studies and shot in the country, followed by Spring (1997), a depiction of springtime at the seashore. His Summer, filmed last summer in the capital of Vilnius, will be released shortly. In The Courtyard the focus is on the casual, indifferent relationship among neighbours living in an apartment house dating from the Interregnum period and has a courtyard used as a playground by children. On the ground floor lives an elderly alcoholic, with his wife and 16-year-old daughter, who spends his time drinking beer with a young unemployed worker. Next door is a old shoemaker with his cats. On the first floor live a young couple who are always going through a crisis. Across the way is an aristocratic grandmother who worries about bad influences on her daughter and granddaughter. Donatas Banionis, after a ten-year absence from the screen, plays the drunkard. Among his many memorable roles were the leads in Grigory Kozintsev's King Lear (1970) and Andrei Tarkovsky's Solaris (1972).

\section{RON HOLLOWAY SPEAKS WITH GILLES JACOB, DIRECTOR OF THE CANNES IN- TERNATIONAL FILM FESTIVAL}

"Nearly all the competition entries are films of and about today," noted Gilles Jacob. "Directors the world over are also looking for new ways to tell stories on film that meet the needs of the new millennium -stylistically, technically, using the entire medium of cinema."

Jacob and his selection staff viewed over 500 feature films, 500 shorts, and 400 student films for the three competitions in this year's programme. The Cinéfondation, started under his aegis two years ago to introduce talent of the future, has grown from two to four programs of 90 minutes apiece -- "full houses are expected in the Salle des Ambassadeurs on Thursday and Friday."

Jacob likes to maintain a "balance" in the competition -- a mixture of art and entertainment. "Sometimes we get both in one film -- as in Pedro Almodóvar's Todo Sobre Mi Madre (All About My Mother) or Atom Egoyan's Felicia's Journey -- that's always a welcomed sign." Both films were press favourites for the Golden Palm.

If there's one criticism of the selection that the festival director is totally in disagreement with, then it's the easy accusation that the same directors are always being invited back to the competition. "Just look at the lineup -- eleven directors, half of the competition, have never competed here before." Without consulting a list, he named Leos Carax (France), Amos Gitai (Israel), Pedro Almodóvar (Spain), Alexander Sokurov (Russia), Yu Lik Wai (China), Tim Robbins (US), Bruno Dumont (France), Takeshi Kitano (Japan), Jacques Maillot (France), John Sayles (US), and Luc and Jean-Pierre Dardenne (Belgium). "And if you wish to add Oliver Parker (Great Britain) on closing night, out-of-competition, that makes a dozen newcomers to the main programme."

Queried about the possibility of future entries arriving in the projection room directly from the film lab, Jacob said: "Those days are over -- at least, I hope so. Since it's possible today to view a work-in-progress on Avid or a video cassette, we now know generally where we stand when we invite a film."

As for the number of journalists invited to attend the festival, he confirmed "it will always remain at a figure under 5,000 -- we can't accommodate any more than that."

But some major changes are coming in the Film Market: "The new building in the back of the Palais will be ready next year -- 8,000 square metres of space and 8 extra screening rooms. It means that we're set for the next five years." He predicted that "a lot of market people will be moving out of hotel rooms, crowded 
foyers, and rented apartments to rent quarters in a new edifice with an attractive view looking directly to the harbour." And he is more than satisfied with the advances made in accommodating the press and media with the latest technological services. "But we always need extra financing from sponsors to meet all our needs -- after all, the government covers only half of our FF 50 million [USD 7.85 million budget]."

Cannes 1999 is the 21st festival with Gilles Jacob as director. Back in 1978, he left his position as film critic at $L ' E x p r e s s$ to succeed Maurice Bessy, but not after spending two years working together with the former director. Asked about persistent rumours that he might retire soon, he said: "Out of the question. I love the job -- so that's the way it will stay, if everyone's happy with me."

Since he sees hundreds of films from around the world, here's some general observations on the current state of film art. Regarding the former Eastern European film lands, "they're coming along very slowly, except for Russia. It was very painful not to be able to invite a film from Hungary this year, not even a short film." Africa is "poor," Latin American "needs more time," but Asia is "very good," and India is "the pleasant surprise of the festival -- particularly the films from Kerala."

Asked if he will be writing his festival memoirs soon, Jacob admitted to "gathering memories," but added: "You can't do the job and comment on it at the same time." So what does he do in his spare time? "I write speeches for my friend Michel Piccoli."

\section{References}

\section{AWARDS}

Golden Palm: Rosetta (Belgium-France), Luc and Jean-Pierre Dardenne

Grand Prize of Jury: L'Humanité (Humanity, France), Bruno Dumont

Best Actress: Émilie Dequenne in Rosetta (Belgium-France) and Séverine Caneele in L'Humanité (Humanity, France)

Best Actor: Emmanuel Schotté in L'Humanité (Humanity, France)

Best Director: Pedro Almodóvar, Todo sobre mi madre (Everything about My Mother, Spain-France)

Best Screenplay: Yuri Arabov, Marina Koreneva, Moloch (Russia-Germany)

Prize of Jury: Manoel de Oliveira, A carta (The Letter, Portugal-France-Spain)

Caméra d'Or (Best First Film): Marana Simhasanam (The Throne of Death, India-UK), Murali Nair

Technical Prize: The Emperor and the Assassin (China-Japan-France), Chen Kaige

Golden Palm, Short Film: When the Day Breaks (Canada), Wendy Tilby, Amanda Forbis

Grand Prize of Jury, Short Film: Stop (France), Rodolphe Marconi

La Cinéfondation Prizes: First Prize: Second Hand (UK-Poland), Emily Young

Second Prize, ex aequo: Im Hukim (With Rules, Israel), Dover Kosashvili, and La Puce (The Flea, France), Emmanuelle Bercot

Third Prize: En God Dag at Go (Little Big Dog, Denmark), Bo Hagen Clausen

Special Mention: Inter-View (Austria), Jessica Hausner

FIPRESCI (International Critics) Prizes

Competition: None

Un Certain Regard: Peau Neuve (New Skin, France), Emilie Deleuze

Quinzaine des Réalisateurs: M-other (Japan), Nobuhiro Suwa

Prix Un Certain Regard: Beautiful People (UK), Jasmin Dizdar

Ecumenical Prize: Todo sobre mi madre (Everything about My Mother, Spain), Pedro Almodóvar 


\section{Author Information}

Ron HOLLOWAY (1933-2009) was an American critic, film historian, filmmaker and correspondent who adopted Europe as his home in the early fifties and spent much of his life in Berlin. He was an expert on the study of German cinema and against all odds produced, with his wife Dorothea, the journal German Film, keeping us up-to-date with the work of directors, producers and writers and the showing of German films around the world.

In 2007, Ron Holloway and his wife were awarded the Berlinale Camera Award. Ron also received the Bundesverdienstkreuz (German Cross of Merit), Polish Rings, Cannes Gold Medaille, the American Cinema Foundation Award, the Diploma for Support of Russian Cinema and an honorary award from the German Film Critics' Association.

Ron was also a valued contributor to Kinema for the past fifteen years. 